Original Article

\title{
Chronic toxicological effects of high diluted solutions of Aveloz (Euphorbia tirucalli L.) on healthy mice: a preliminary study
}

\author{
Marcia CBN Varricchio ${ }^{1}$ (DSc), Cristiane Pereira ${ }^{1}$, Fernanda Sales ${ }^{1}$, Teresa Gomes ${ }^{1}$, Elaine \\ Daudt $^{2}$, Carolina Lessa Aquino², Gleyce Moreno Barbosa ${ }^{1}$, Nelson Gomes, Alexandre dos \\ Santos Pyrrho ${ }^{1}$ (DSc), Paulo Eduardo Mansur Hobaica ${ }^{1}$, Morgana Castelo Branco $^{1}$ (DSc), \\ Ricardo Kuster ${ }^{1}$, Carla Holandino ${ }^{1}$ (DSc)
}

(1) Federal University of Rio de Janeiro, (2) University of Rio de Janeiro, RJ, Brazil

\begin{abstract}
The latex extracted from Euphorbia tirucalli, a plant popularly known as Aveloz, is used in complementary medicine to induce tumor regression. However, as this latex has toxic effects when administered orally in ponderal doses, the present study was designed to assess the effects of high dilutions in healthy mice over a period of 18 weeks. The Aveloz latex-high diluted solutions (latex-HD) were obtained through the interaction of two processes: 1:100 dilution in mass and succussion, using ethanol $70 \%$ as a solvent, in the homeopathic dilutions of 5,15 and $30 \mathrm{cH}$, following Farmacopéia Homeopática Brasileira. Control solutions without latex were compounded (ethanolic-HD) in the same dilutions and were administered simultaneously. The animals which received latex-HD $30 \mathrm{cH}$ showed a significant increase in food consumption $(p<$ $0.05)$ without significant difference in weight gain. In regards to water consumption, no statistical difference was shown when different Aveloz latex-HD groups were compared, apart from the group that received 1 drop of pure latex in water, which presented a significant increase $(p<0.05)$ in this parameter.
\end{abstract}

Keywords: Euphorbia tirucalli; Aveloz; Toxicology; High Dilutions; Mice.

\section{Introduction}

Euphorbia tirucalli L. popularly known as Aveloz, is a succulent plant with cosmopolitan distribution. It has nefro and hepatotoxic effects, besides immunosuppressive action and tumor co-promoting activity due to the presence of phorbol esters in the latex. These esters are present in the latex in nano molar concentration [1-2]. Nevertheless, oral administration of the latex diluted in water is often used in popular medicine to treat chronicdegenerative diseases [3-4]. These phorbol esters can be modified by several chemical and physical processes as well as by biotransformation in living organisms through esterase digestion [5]. There are no scientific reports regarding the use of diluted and agitated solutions prepared from Aveloz latex trituration indicating biological effects on healthy mice. The aim of this study is to compare the possible chronic toxicological effects of the latex of Euphorbia tirucalli administered orally ad libitum in both ponderal doses and in high diluted and agitated preparations $(5 \mathrm{cH}, 15 \mathrm{cH}$ and $30 \mathrm{cH})$ on aspects of the development of healthy mice over 18 weeks.

\section{Materials and Methods}

For this study, the authorization by the Committee for Evaluation of Animal Use in Research from Federal University of Rio de Janeiro (CAUAP UFRJ) was obtained under registration number DAHEICB001. Tests were conducted under conditions that guaranteed animal care and welfare, according to the $3 \mathrm{R}$ rationality principles for animal experimentation. The homeopathic solutions were prepared following the technique recommended by Brazilian Homeopathic Pharmacopoeia for insoluble actives [6]. Briefly, $0.15 \mathrm{~g}$ of E. tirucalli latex were collected in $14.85 \mathrm{~g}$ of lactose and were triturated in a porcelain grail $(1 \mathrm{cH})$ sequentially repeated until reaching dilution $3 \mathrm{cH}$, followed by solubilization in ethanol $20 \%$ and succussion to obtain dilution $4 \mathrm{cH}$ [6]. Dilution $5 \mathrm{cH}$ was prepared by mixing 1 part of dilution $4 \mathrm{cH}$ in 99 parts of ethanol $70 \%(\mathrm{~V} / \mathrm{V})$. This procedure of dilution 1:100 and mechanical sucussion (Denise 10-50, AUTIC) was repeated until 
dilution $30 \mathrm{cH}$ was reached; these solutions were named Latex-HD, as previously described [7]. In order to register eventual chemical effects of Aveloz latex or systematic experimental errors in the dilutions, an equivalent set of control samples not containing the active principle (Ethanol-HD) was prepared under the same conditions. Latex-HD and the respective controls were prepared in homeopathic preparations $5 \mathrm{cH}, 15 \mathrm{cH}$ and $30 \mathrm{cH}$. The effects of ponderal doses of the latex (1 drop and 10 drops diluted in $500 \mathrm{ml}$ in the animals' drinking water) were also evaluated.

Fifty healthy Swiss female mice, age 4 months and mean weight 20 grams were distributed into 10 groups of 5 animals. Each group received a specific solution offered orally ad libitum over a period of 18 weeks, diluted in the animals' drinking water. Each group received, diluted in $500 \mathrm{ml}$ of their drinking water: distilled water (control group), 1 drop of latex and 10 drops of latex (ponderal effect), 10 drops of Latex-HD and 10 drops of Ethanol-HD, respectively. The animals' weight, food and water consumption in each experimental group were evaluated in the first (time zero) and each following week, through gravimetric (weigh and food consumption) and volumetric (water consumption) assays. Mobility was evaluated through the neurological semiotechnic standard scale [8].

At the end of the experiment, statistical analyses were obtained: average and standard deviations of each experimental situation and variance analyses were accomplished through Graph Pad Instat software (2000). In all analyses, confidence interval was $95 \%$ and $p$ values less than 0.05 were considered significant.

\section{Results and Discussion}

There was no significant variation in the animals' mobility (Figure 1) and weight (Figure 2) among the several Ethanol-HD and control groups analyzed $(p>0.05)$. However, from the fifth week on, an increase in food consumption was detected in the group that ingested Aveloz-latex-30cH ( $p>0.05)$ by comparison to the animals in the other groups (Figure 3). There was no significant difference in water consumption among the different groups of animals $(p>0.05)$. However, the group that received 1 drop of latex in distilled water ad libitum (ponderal effect) showed a significant increase $(p>0.05)$ in the amount of water intake (Figure 4).

Figure 1: Weekly mobility of Swiss mice receiving orally ad libitum over 18 weeks the following solutions: distilled water (DW); 1 drop of Aveloz latex (Lx 1); 10 drops of Aveloz latex (Lx 10); 10 drops of ethanol 70\%v/v (ETOH 70\%); 10 drops of ethanol $5 \mathrm{cH}(\mathrm{ETOH} 5 \mathrm{cH}) ; 10$ drops of Aveloz latex $5 \mathrm{cH}(\mathrm{Lx}-\mathrm{HD} 5 \mathrm{cH}) ; 10$ drops of ethanol 15cH (ETOH $15 \mathrm{cH}) ; 10 \mathrm{drops}$ of Aveloz-latex 15cH (Lx-HD $15 \mathrm{cH}) ; 10$ drops of ethanol 30cH (ETOH 30cH); 10 drops of Aveloz-latex 30cH (Lx-HD 30 cH) diluted in the animals' drinking water.

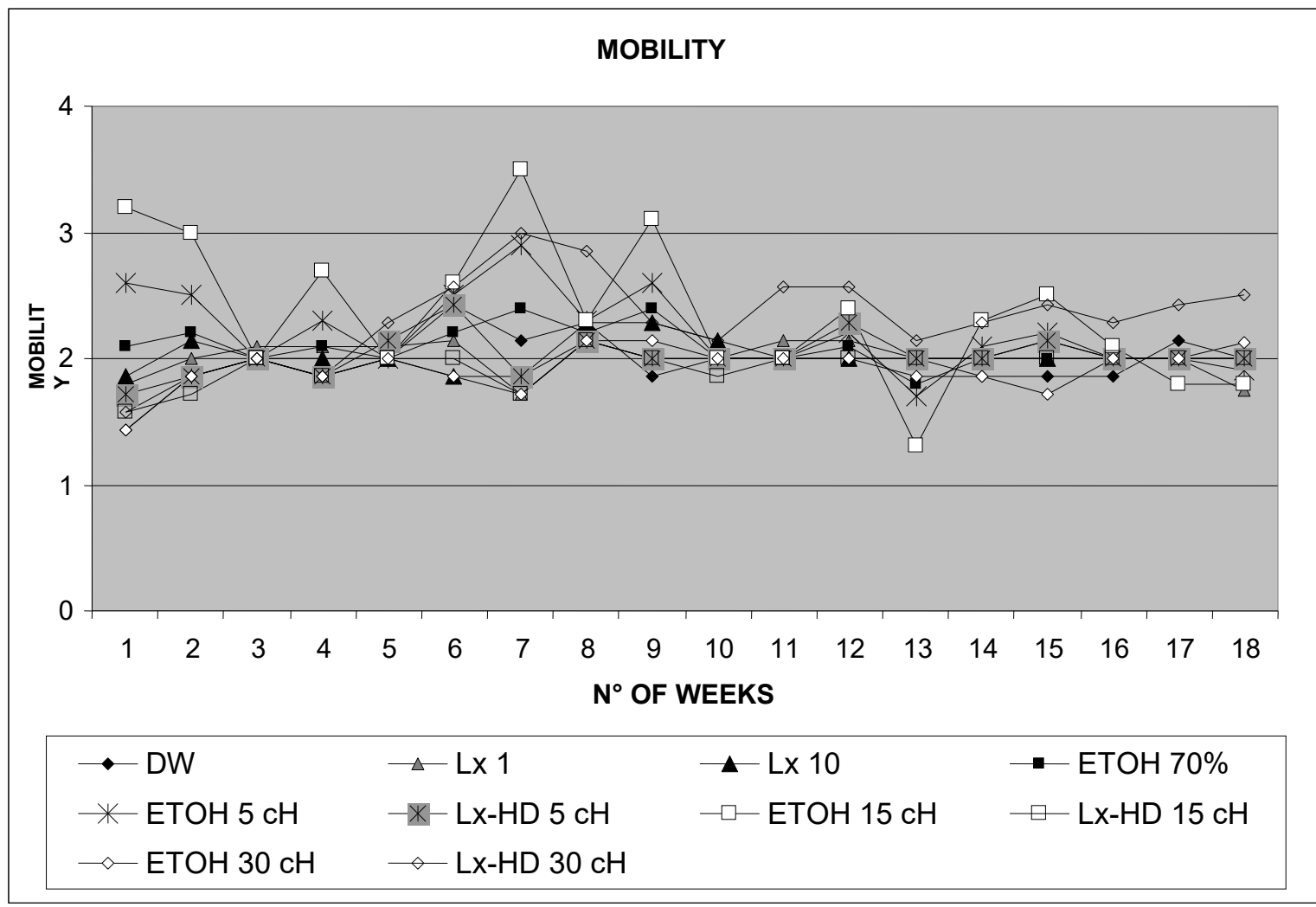

DW: distilled water; ETOH: ethanol; Lx: Aveloz latex; Lx-HD: Aveloz latex high dilutions; cH: centesimal Hahnemannian. 
Figure 2: Weekly weight of Swiss mice receiving orally ad libitum over 18 weeks the following solutions: distilled water (DW); 1 drop of Aveloz latex (Lx 1); 10 drops of Aveloz latex (Lx 10); 10 drops of ethanol 70\%v/v (ETOH 70\%); 10 drops of ethanol 5cH (ETOH $5 \mathrm{cH}) ; 10$ drops of Aveloz-latex $5 \mathrm{cH}(\mathrm{Lx}-\mathrm{HD} 5 \mathrm{cH}) ; 10$ drops of ethanol 15cH (ETOH $15 \mathrm{cH}) ; 10 \mathrm{drops}$ of Aveloz-latex $15 \mathrm{cH}(\mathrm{Lx}-\mathrm{HD} 15 \mathrm{cH}) ; 10$ drops of ethanol 30cH (ETOH 30cH); 10 drops of Aveloz-latex 30cH (Lx-HD 30 cH) diluted in the animals' drinking water.

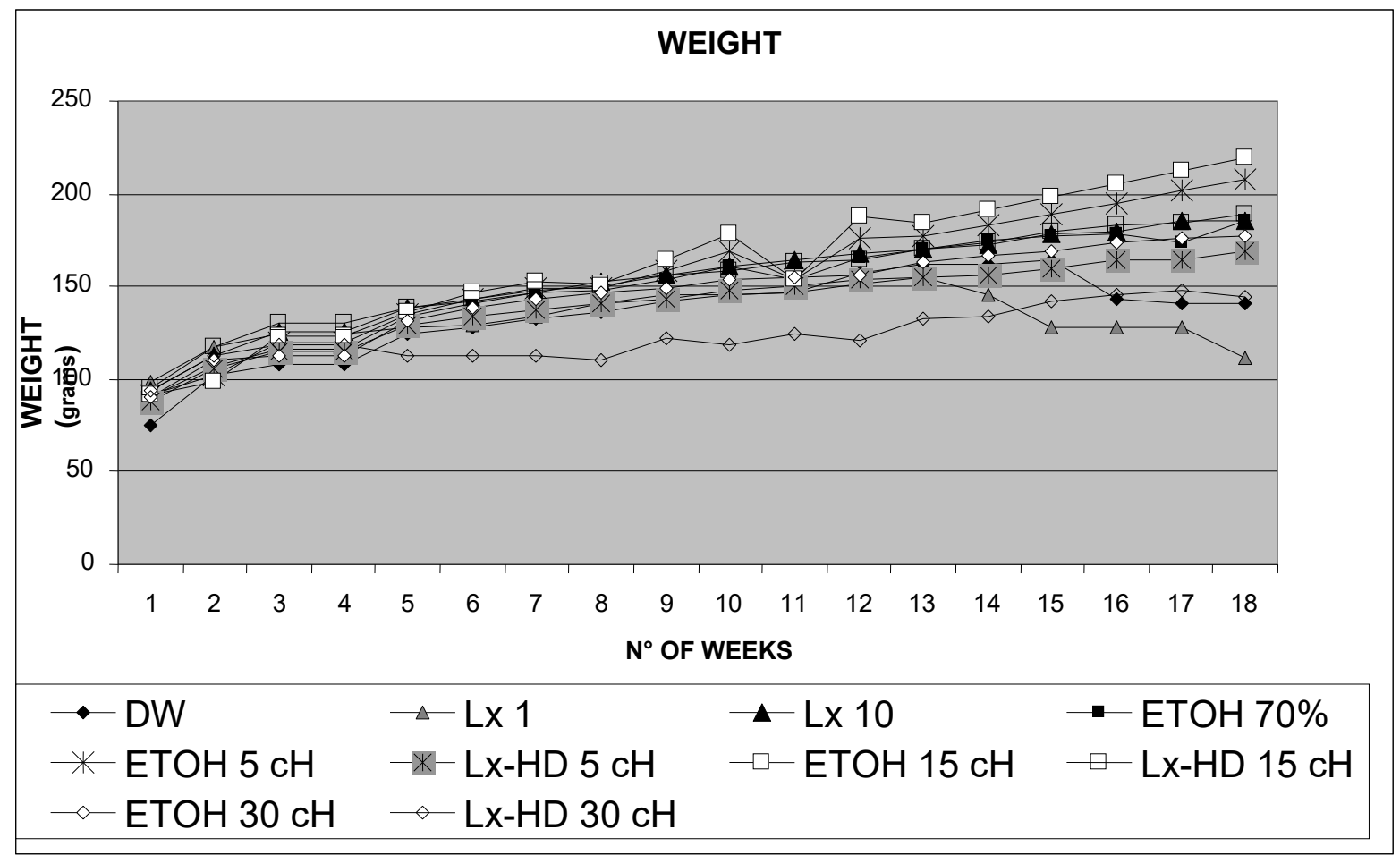

DW: distilled water; ETOH: ethanol; Lx: Aveloz latex; Lx-HD: Aveloz latex high dilutions; cH: centesimal Hahnemannian.

Figure 3: Weekly average variation of food consumption of Swiss mice receiving orally ad libitum over 18 weeks the following solutions: distilled water (DW); 1 drop of Aveloz latex (Lx 1); 10 drops of Aveloz latex (Lx 10); 10 drops of ethanol $70 \% \mathrm{v} / \mathrm{v}$ (ETOH 70\%); 10 drops of ethanol $5 \mathrm{cH}(\mathrm{ETOH} 5 \mathrm{cH}) ; 10$ drops of Aveloz-latex 5cH (Lx-HD 5cH); $10 \mathrm{drops}$ of ethanol $15 \mathrm{cH}(\mathrm{ETOH} 15 \mathrm{cH}) ; 10$ drops of Aveloz-latex 15cH (Lx-HD 15cH); 10 drops of ethanol 30cH (ETOH 30cH); $10 \mathrm{drops}$ of Aveloz-latex $30 \mathrm{cH}(\mathrm{Lx}-\mathrm{HD} 30 \mathrm{cH})$ diluted in the animals' drinking water.

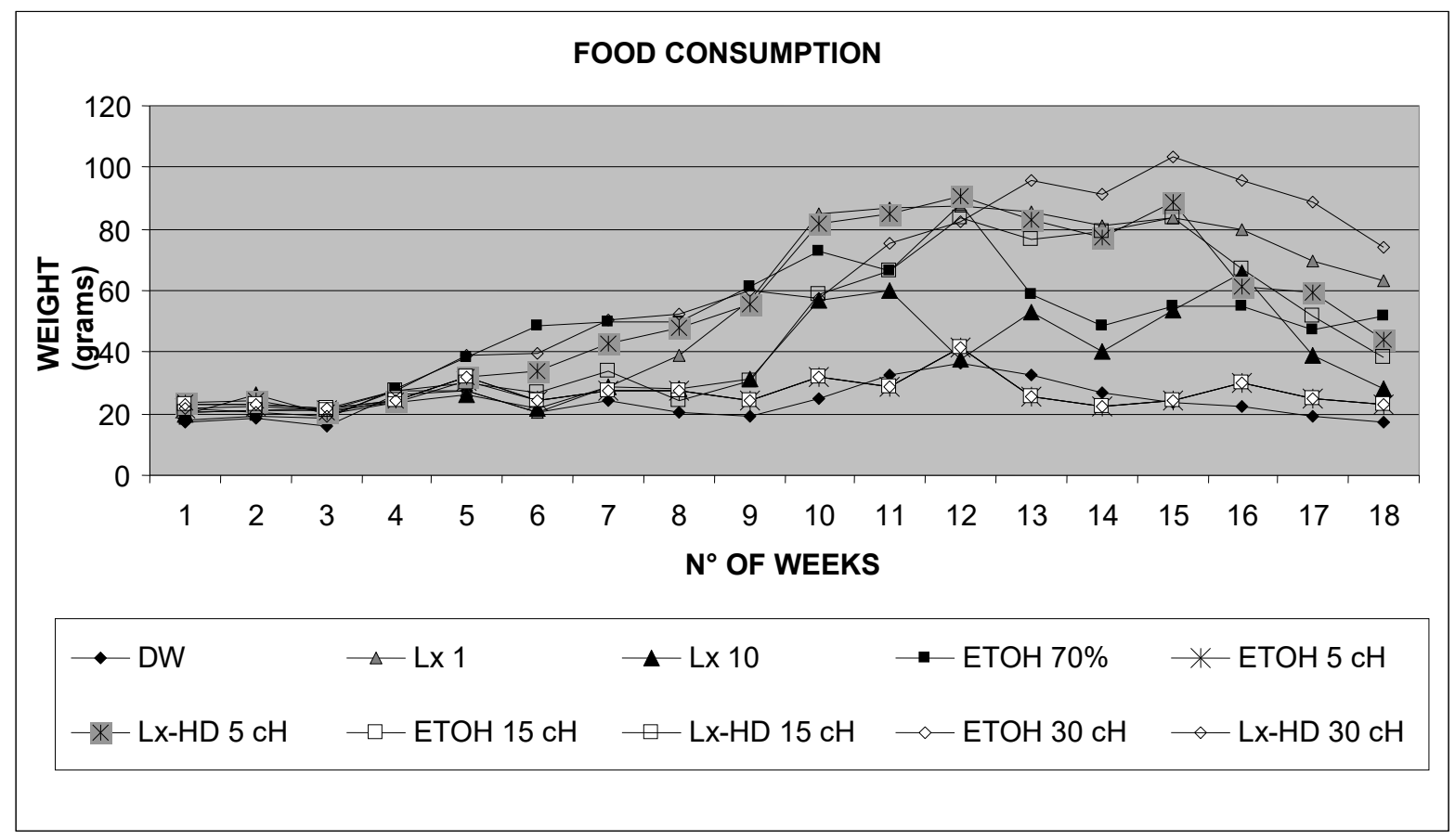

DW: distilled water; ETOH: ethanol; Lx: Aveloz latex; Lx-HD: Aveloz latex high dilutions; cH: centesimal Hahnemannian. 
Figure 4: Weekly average variation of water consumption of Swiss mice receiving orally ad libitum over 18 weeks the following solutions: distilled water (DW); 1 drop of Aveloz latex (Lx 1); 10 drops of Aveloz latex (Lx 10); 10 drops of ethanol $70 \% \mathrm{v} / \mathrm{v}(\mathrm{ETOH} 70 \%) ; 10$ drops of ethanol 5cH (ETOH $5 \mathrm{cH}) ; 10$ drops of Aveloz-latex 5cH (Lx-HD 5cH); 10 drops of ethanol $15 \mathrm{cH}(\mathrm{ETOH} 15 \mathrm{cH}) ; 10$ drops of Aveloz-latex 15cH $(\mathrm{Lx}-\mathrm{HD} 15 \mathrm{cH}) ; 10$ drops of ethanol 30cH $(\mathrm{ETOH} 30 \mathrm{cH}) ; 10 \mathrm{drops}$ of Aveloz-latex $30 \mathrm{cH}(\mathrm{Lx}-\mathrm{HD} 30 \mathrm{cH})$ diluted in the animals' drinking water.

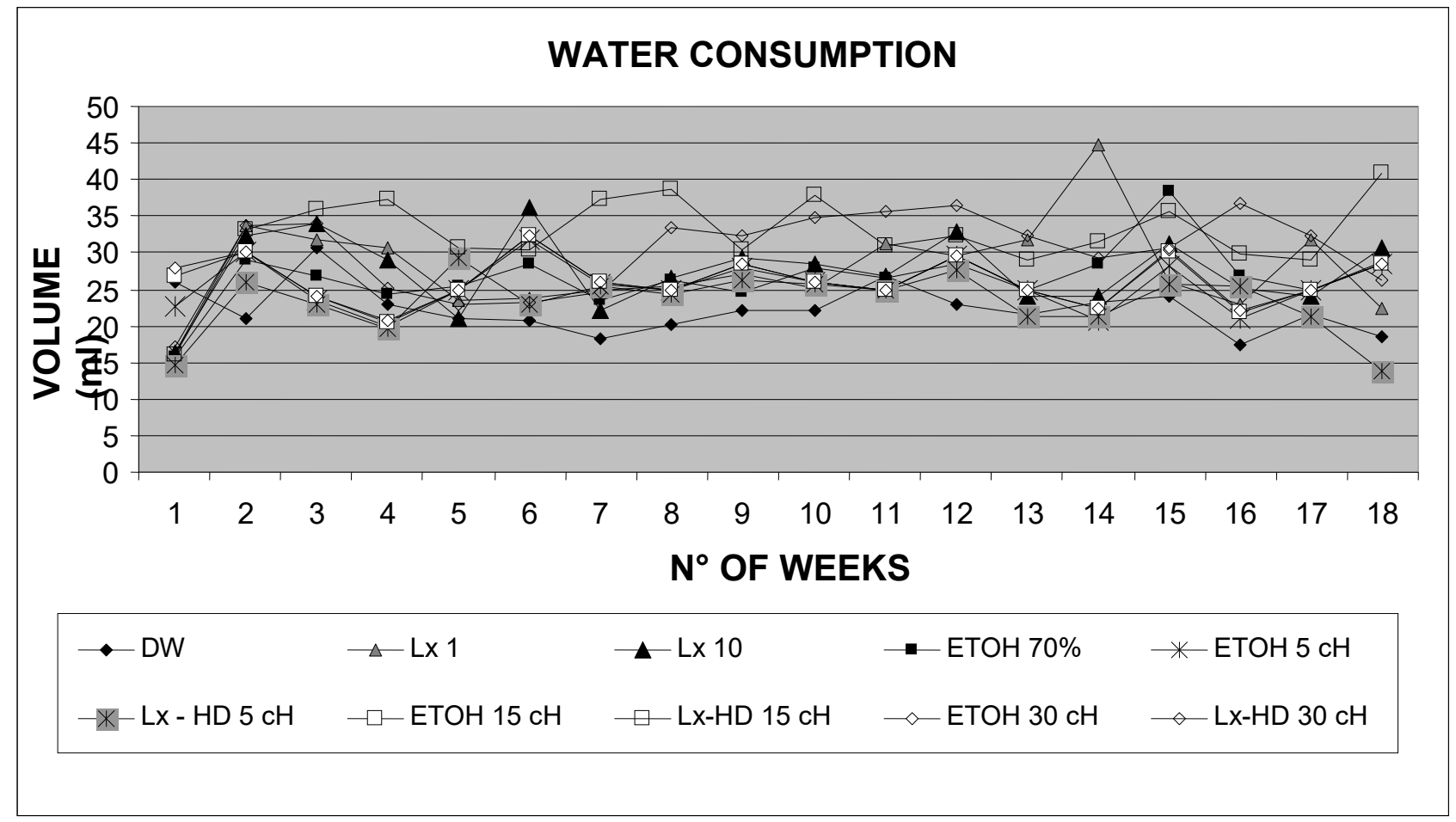

DW: distilled water; ETOH: ethanol; Lx: Aveloz latex; Lx-HD: Aveloz latex high dilutions; cH: centesimal Hahnemannian.

This preliminary observation of the toxic effects of high diluted solutions of E. tirucalli indicated that only Avelox-latex-30cH was able to produce significant changes in the animals' metabolism, expressed as increase in food consumption and other biochemical features (data not shown). Indeed, Williams \& Wilson [9] stated that phorbol esters, molecules present in the aerial parts of plants of the genera Euphorbia, are able to stimulate. Thyrotropin-releasing hormone (TRH) induces secretion of the thyroid-stimulating hormone (TSH) by hypophysis. In the animal group that received Aveloz-latex $30 \mathrm{cH}$ one death occurred, but necropsy was not possible due to the state of decomposition.

Finally, the lack of effects of Aveloz latex in ponderal doses and in dilutions $5 \mathrm{cH}$ and $15 \mathrm{cH}$ on healthy animals differed from those described by Nawito and colleagues [10] in a toxicological study in goats with ponderal doses of latex of E. peplus. These animals showed reduction in food ingestion, decrease in mobility and significant weight gain with concomitant formation of widespread edema.

\section{Conclusions}

The results obtained in this study contribute to current basic research on Aveloz in ponderal and high diluted and agitated solutions shedding light on the effects of Euphorbia tirucalli L. on healthy animals. This line of research will be complemented by biochemical analyses on blood and hystopathological analyses of the animal organs used in study reported here to bring new data to the ongoing investigation.

\section{Acknowledgments}

This work was supported by grants from the following Brazilian agencies: Conselho Nacional de Pesquisas (CNPq); Fundação de Amparo à Pesquisa do Estado do Rio de Janeiro (FAPERJ); Fundação José Bonifácio (FUJB). The authors are grateful to Roberta Ghilosso Bortolini MSc for help in preparing the manuscript and to Maria Cristina Lana Chaves de Castro MA for English language revision.

\section{References}

[1] Ito Y. Combined effect of the extracts from Croton tiglium, Euphorbia lathyris or Euphorbia tirucalli and n-butyrate on Epstein - Barr virus expression in human lymphoblastoid P3HR-1 and Raji cells. Cancer Lett. 1981; 12: 175-180.

[2] van den Bosch CA. Is endemic Burkitt's lymphoma an alliance between three infections and 
a tumor promoter? Lancet Oncol. 2004; 5 (12): 738746.

[3] Imai S, Sugira M, Mizuno F, Ohigashi H, Koshimizu K, Chiba S, et al. African Burkitt's lymphoma: a plant, Euphorbia tirucalli, reduces Epstein-Barr Virus-Specific Cellular Immunity. Anticancer Res. 1994; 14(3A): 933 - 936.

[4] Furstenberg G, Hecker E. On the active principles of the Euphorbiaceae, XII. Highly unsaturated irritant diterpene esters from Euphorbia tirucalli originating from Madagascar. J Nat Prod. 1986; 49(3): 386 - 397.

[5] Nelson DL, Cox MM, editors. Princípios de bioquímica. São Paulo: Sarvier; 2002.

[6] Farmacopéia Homeopática Brasileira. 2nd ed. São Paulo: Atheneu; 1997.

[7] Aquino CL, Barbosa GM, Barbosa GM, Varricchio MCBA, Veiga VF, Kuster R, Zancan P, Sola-Penna M, Quaresma CH. High dilutions of
Euphorbia tirucalli L. (AVELOZ) modify the viability and glycolytic metabolism of cell lines. Int $\mathrm{J}$ High Dilution Res [online]. 2008 [cited 2008 Sep 20]; 7(24): 132-139. Available from: http://www.feg.unesp.br/ ojs/index.php/ijhdr/article/ view/283/361.

[8] Wolfensohn S, Lloyd M, editors. Handbook of laboratory animal management and welfare. Oxford: Oxford University Press; 1994.

[9] Williams RH, Wislon JD, editors. Williams textbook of endocrinology. 9th ed. Philadelphia: WB Saunders Company; 1998.

[10] Nawito M, Ahmed YF, Zayed SM, Hecker E. Dietary cancer risk conditional cancerogens in produce of livestock fed on species of spurge (Euphorbiaceae). II. Pathophysiological investigations in lactating goats fed on the skin irritant herb Euphorbia peplus and in their milkraised kids. J Cancer Res Clin Oncol. 1998; 124(3-4): 179- 185 .

\section{(c)) EY-No-ND Licensed to GIRI}

Support: FAPERJ, FUJB, CNPq

Conflict of interest: authors declare there is no conflict of interest

Received: 27 Sep 2008; Revised 21 Nov 2008; Published: 19 Dec 2008

Erratum: 30 Dec 2008. (http://www.feg.unesp.br/ ojs/zacha_ijhdr/erratum/?v=7\&i=25\&pi=174)

Correspondence author: Carla Holandino Quaresma, cholandino@yahoo.com

How to cite this article: Varricchio MCBN, Pereira C, Sales F, Gomes T, Daudt E, Aquino CL, Barbosa GM, Gomes N,

Pyrrho AS, Hobaica PEM, Branco MC, Kuster R, Holandino C. Chronic toxicological effects of high diluted solutions of

Aveloz (Euphorbia tirucalli L.) on healthy mice: a preliminary study. Int J High Dilution Res [online]. 2008 [cited YYYY

Mmm DD]; 7(25): 174-178. Available from: http://www.feg.unesp.br/ ojs/index.php/ijhdr/article/view/308/371. 